\title{
An Assessment of Foreign Direct Investment and Sustainable Development Nexus: The Nigerian and Ghanaian Perspectives
}

\author{
Nkemdilim Iheanachor ${ }^{1}$ \\ *Azuka Elvis Ozegbe ${ }^{2}$ \\ 'Lagos Businesss School, Liagos, ligeria

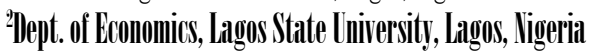

\begin{abstract}
This study explored contribution of foreign direct investment (FDI) inflows to the sustainable development of the Nigerian and Ghanaian economies. The investigation was prompted by the apparent evidence of rising FDI inflows in the last two decades, which has failed to improve both nations' sustainable development drive significantly. The study employed the ordinary least square (OLS) econometric technique to test the effect of FDI inflows on sustainable development indicators using annual times series data from 2000 to 2018 obtained from both countries' World Development Indicators (WDI) for the period covering the Millennium Development Goals (MDG) era and the earlier stages of the Sustainable Development Goals (SDG) of the United Nations (UN). The findings revealed that Ghana performed better than Nigeria on social sustainability, measured in terms of education and healthcare indicators. However, on environmental and economic sustainability, Nigeria fared better. A percentage increase in FDI inflow to both countries enhances economic growth and economic sustainability by 0.30 percent. However, study indicated that the positive impact is statistically insignificant. This reveals that the difference in economic growth and economic sustainability in both countries is not accounted for by FDI.

Keywords: Foreign direct investment (FDI), sustainable development, ordinary least square (OLS), Nigeria, Ghana

JEL: F21, 011, 047
\end{abstract}

Demographically, Nigeria and Ghana represent the two most critical anglophone countries in the westAfrican sub-region, and they have been the leading economic powerhouses in that bloc (Egbunike et al., 2018). Although the two countries have many common features, their economic performances and developmental strides seem to have differed considerably in recent years. However, both countries have significantly benefitted from the inflow of foreign direct investment (FDI) into their respective economies (Acquah and Ibrahim, 2020; Umoh et al., 2012; Antwi et al., 2013). The African economies rely on FDI inflows from the developed countries to attain the much-desired sustainable growth and development in the region. Though the region has recorded some impressive growth in recent times, its ability to sustain it calls for concern. This is because one of the growth-enhancing factors in the region has unfortunately slumped since 2015. Available statistical evidence (WDI, 2019) reveals that much of the region's countries have been unable to attract adequate FDI in recent years. 
For instance, in 2000, Nigeria attracted a US\$1,140,138 FDI inflow while Ghana welcomed FDI worth US\$165900. Half a decade later, FDI inflow to Nigeria increased to US\$4,982,534 while that of Ghana declined to US\$144970. FDI inflow continued to expand into Nigeria up to 2010 when it reached US $\$ 6,026,232$, and Ghana's case was US $\$ 2,527,350$. Due to political and social challenges like insecurity and pre-electoral uncertainties, FDI inflows into Nigeria plummeted by over 50 percent to US $\$ 3,128,592$ while that of Ghana marginally increased to US\$3,192,321.

Despite the New Partnership for Africa's Development (NEPAD) initiative by the African Union in 2001 to pursue new priorities and approaches to the socio-economic and political transformation of Africa for sustainable development in the region through foreign investment, the impact of the initiative has left more to be desired, which apart from being disturbing presently, it does not raise the possibility for economic development and growth in the near future.

This paper is motivated by the fact that despite the relative rise in international flows such as FDI, trade, and foreign aid since the new millennium's turn in 2000, economic, social and environmental sustainability continued to nosedive in both economies. From the preceding, some critical questions arose. For instance, what is the impact of FDI inflows on the Nigerian and Ghanaian economies' economic, social, and environmental sustainability? Does FDI have a long-term relationship with sustainable development in both economies? The answer to these weighty questions will provide insight into the welfare implication of FDI inflows to the economic, social, and environmental sustainability of both economies.

Several inquiries have been conducted to examine the relationship between FDI and economic growth in various countries. For instance, scholars such as Agyemang et al. (2019) examined the nexus between national-level corporate governance and FDI in African countries between 2009 and 2015. Evans and Kelikume (2018) explored the effects of FDI, trade, aid, remittances, and tourism on welfare under terrorism and militancy in Nigeria. Djokoto (2012) evaluated domestic and foreign direct investment in the Ghanaian agricultural sector. Alfaro (2017) investigated how and when does FDI promote growth in emerging markets. Srinivasan et al. (2011) conducted an empirical investigation on FDI inflows and SAARC economies' growth. In the same vein, Insah and Ofori-Boateng (2012) examined foreign direct investment inflows and economic growth in Ghana for the study period, which spanned 1980 to 2010. However, as far as we know, no investigations have been carried out to succinctly examine the impact of FDI on economic, social, and environmental sustainability stemming from empirical evidence from developing countries like Nigeria and Ghana. To close the research gaps and improve the limitations of extant studies, this study built its hypothesis on the Harrod (1948) and Domar (1957) two-gap theory.

Therefore, the purpose of this investigation is to examine the impact of FDI on sustainable develop- 


\section{Iheanachor \& Ozegbe}

ment in Nigeria and Ghana. The article deployed the ordinary least square (OLS) technique to empirically test the framework built on the Harrod (1948) and Domar (1957) two-gap theory. The twogap growth theory opines that foreign capital inflows can accelerate an economy's growth rate by raising the availability of capital for production, where the capital-output ratio is held constant (Harrod, 1948; Domar, 1957).

The contribution of this paper to knowledge is three-fold. First, it extended the Harrod-Domar two gaps model to the environmental and social conditions that affect the FDI of host economy. To this end, the study's results support the fact that social, environmental, and economic conditions are critical considerations for the inflows of FDI. Second, the study is the first to the best of our knowledge to have empirically ascertained how FDI influences sustainable development through health, education, environment, and growth. Third, the study improved on previous studies by utilizing the ordinary least square technique. This method is simple, efficient, and consistent; it produces unbiased results that are reliable and valid for policy suggestions.

The study is outlined as follows. The second section contains the theoretical and empirical review of the literature. Section three contains methodology, section four details the study's analysis, and section five discusses the findings, section six presents the conclusion based on the results, and section seven provides implications and future research directions.

\section{LITERATURE REVIEW}

\section{Theoretical Underpinnings}

The pioneering Harrod-Domar model $(1939,1946)$ remains a critical reference in the economics of investment. It explains the importance of ascertaining the rate of investment required to attain a given rate of economic growth (Evans and Kelikume, 2018; Sakyi and Egyir, 2017). Similarly, the role of foreign investment (in the form of FDI) in economic growth has been recognized as key in the literature (See Agyemang et al., 2019; Alfaro, 2017; Flora and Agrawal, 2017; Melane-Lavado et al., 2018; Koojaroenprasit, 2012). However, this role of FDI in economic growth is highly controversial. The proponents of FDI argued that FDI augments capital formation in the host country and promotes economic growth (e.g., Acquah and Ibrahim, 2020; Bermejo and Werner, 2018; Pandya and Sisombat, 2017; Zekarias, 2016). On the contrary, opponents of FDI argued that FDI hurts growth (e.g., Dinh et al., 2019; Masipa, 2018; Siddique et al., 2017). Remarkably, the existing literature is much concentrated on investigating the broad effects of FDI on growth. The contribution of FDI to sustainable development has attracted very little attention, in general.

\section{-The Two Gaps Model (Harrod-Domar Theory)}


Sir Fredrick Harrods (1948) and Evsey Domar (1957) attributed economic growth to total national savings, capital efficiency (MEC), and depreciation in capital stock. In their earlier analysis, the growth model was limited to the closed economy. Thus:

$$
\begin{aligned}
& \mathrm{Yg}=f(\mathrm{~s}, \mathrm{k}, \delta) \\
& \mathrm{Yg}=\beta(\mathrm{s})-\delta
\end{aligned}
$$

In the review of this theory, the early model of Harrod and Domar ( $\mathrm{H}-\mathrm{D}$ model) was built on the assumption of variables under consideration. Furthermore, technical progress was neglected as a critical determinant of growth, and finally, the assumption of fixed factor intensity, which does not allow factor substitution, is unrealistic.

In a revised work by the authors, the model was extended to the external sector, which showed that foreign capital inflows play an amplifying role in achieving economic growth. This version of the $\mathrm{H}-\mathrm{D}$ model proved relevant to less developed countries, (LDCs) like Nigeria and Ghana, lacking the required savings capacity to command the minimum necessary investment for growth. Nevertheless, the extension of the external sector's scope opens up opportunities for LDCs to obtain funds from the international market for domestic investments to attain the desired growth rate.

The model of $\mathrm{H}-\mathrm{D}$ with international sector consideration is:

$$
\mathrm{Yg}=\beta(\mathrm{s}+\mathrm{f})-\delta
$$

Where $\beta \cdots$ MEC

s $\cdots$ savings

$f \cdots \cdots$ foreign capital inflow $((\mathrm{f} / \mathrm{y}))$

$\delta \cdots \cdot \cdot$ depreciation.

\section{Two- Gaps Theory, Foreign Direct Investment and Sustainable Development}

Investigations on the impact of foreign direct investment on economic growth or sustainable economic development have been conducted by some scholars using Harrod (1948) and Domar (1957) two-gap growth theory. For instance, Voica et al. (2015) examined the nexus between FDI and sustainable development using the two-gap model and found several links to achieve SDGs through investments. The study also found the importance of FDI, specifically for environmental projects to improve greenhouse effects along with promoting social and economic goals. Flora and Agrawal (2017) revealed a robust causal linkage running from FDI to enhanced skilled labor wages, advanced technology and sustainable development. Melane-Lavado et al. (2018) explored innovative ways for sustainable development and identified a positive impact of FDI based on small and medium organizations related to technology supply.

The FDI also influences the environment and the economic components of sustainable develop- 


\section{Iheanachor \& Ozegbe}

ment. Even a favoring effect of FDI on poverty was identified by Gohou and Soumare (2012) in Africa. However, the impact was higher in poor regions as compared to wealthier regions. Agyemang et al. (2019) examined the link between country-level corporate governance and FDI in African economies for 2009 to 2015. The authors used annual time series data of 40 African countries and deployed the generalized system method of moments (GMM) to explore a correlation between country-level corporate governance and FDI. The authors found that African economies comprised of firms with high-level ethical values tend to experience more significant FDI inflows than those lacking the same. Djokoto et al. (2012) evaluated domestic and foreign direct investment in the Ghanaian agricultural sector. They used time-series data from 1976 to 2007 and revealed that FDI into the Ghanaian agricultural sector crowd-in domestic investment and found that FDI does not have a significant impact on Ghanaian agricultural sector. Alfaro (2017) investigated how and when does FDI promote growth in emerging markets. The study noted that the mechanism by which multinational activities might build direct impacts and externalities to economies and the role complementing domestic environment also referred to as "absorptive capacities" that enable a nation to harvest the gains of FDI by focusing on factor market reallocation effects and the interaction between domestic and foreign firms. Srinivasan et al. (2011) conducted an empirical investigation of FDI inflows and growth in the economies of SAARC. The study employed Johansen's cointegration test to determine the long-run relationship between FDI and GDP for the SAARC economies under investigation, namely, Bangladesh, India, Maldives, Nepal, Pakistan and Sri Lanka, and found a positive relationship between both variables within the period of investigation. Shuaib et al. (2015) used Harrod (1948) and Domar (1957) two-gap model to explore the effects of FDI on the growth of the Nigerian economy using time series data from 1981 to 2013. The study found that there is no significant relationship between FDI and economic growth in Nigeria.

It is unclear from the empirical and theoretical review above whether FDI has positive or adverse effects on sustainable development. None of the previous studies has been carried out to succinctly examine the impact of FDI on sustainable development stemming from empirical evidence from developing countries like Nigeria and Ghana. As such, to close the empirical and theoretical gaps identified in the literature, this study proposes to test the following hypothesis.

$\mathrm{H}_{0}$ : FDI has no impact on sustainable development in Nigeria and Ghana.

If our test results permit us to reject this hypothesis, it would mean that the variables are indeed cointegrated and FDI has a positive impact on sustainable development between both nations. Apart from this, we shall be testing other minor hypotheses relating to unit root and serial correlation. 


\section{METHODOLOGY}

\section{Sample and Data}

This section is concerned with the method of gathering and analyzing data for this study. This aims to determine the long-run relationship between foreign direct investments (FDIs) and sustainable development in the Nigerian and Ghanaian economy. The rationale behind both countries' choice for this study is that both economies account for more than 65 percent of the regions FDI inflows in the last four decades. Also, both nations' economies constitute approximately 78 percent of the subregion's economy, with a GDP of $\$ 466.87$ billion and $\$ 66.7$ billion, respectively. In selecting the sampled countries, the study employed a purposive sampling technique which justifies making theoretical, analytical and logical generalization from the sample that is being studied.

This paper, therefore, adopts the multiple regression analysis with the ordinary least square (OLS) econometric technique on a time series secondary data from 2000 to 2018 . The data were obtained from Nigeria's World Development Indicator (WDI) (2018) for the period under review represents the MDG era and the earlier stages of the UN's SDG. This enabled us to reach desirable conclusions on whether there is a long-run relationship between FDI and sustainable development in Nigeria and Ghana's economy.

The study applies time series data drawn from Foreign Direct Investment (FDI), Real Gross Domestic Product (RGDP) as a proxy for economic growth, Gross Fixed Capital Formation (GFCF), Carbon-dioxide emission as a proxy for environmental sustainability $\left(\mathrm{CO}_{2}\right)$, and social development proxied by government expenditure on health and education (PSE) for Nigeria and Ghana obtained from the World Development Indicator (WDI, 2018) and the apex bank of the countries.

\section{Model Specification}

Using the two gaps model propounded by Harrod (1948) and Domar (1957) as well as the frameworks posited by Boianovsky (2017), Eltis (2016), and Masoud (2014), and the empirical works of Coccia (2019), Evans and Kelikume (2018), Peprah et al. (2019). This study's model specification follows an earlier study conducted by Frimpong (2012), which examined FDI inflows and trade between China and Ghana. Our study departs from Akpo and Hassan (2015) and Choi and Baek (2017) by extending the impact of FDI on sustainable development, which has its economic, social, and environmental components.

$$
\begin{gathered}
\ln R G D P_{t}=\alpha \ln F D I_{t}+\beta \ln G F C F_{t}+\mu_{t} \\
C O 2_{t}=\delta \ln F D I_{t}+\gamma \ln R G D P_{t}+\mu_{t} \\
\ln P S E_{t}=\theta \ln F D I_{t}+\pi \ln R G D P_{t}+\mu_{t}
\end{gathered}
$$




\section{Iheanachor \& Ozegbe}

Where $\alpha>0, \beta>0, \delta>0, \gamma>0, \theta>0, \pi>0$

\section{Analysis}

\section{-Trends Analysis}

Figures 1 to 7 (see Appendix-I) depict the behavior of various development indicators in both countries. For instance, Figure 1 shows that FDI inflow in Nigeria is higher than that of Ghana for all years between 2000 and 2018 except 2015, where Ghana recorded a marginally higher FDI than Nigeria. This could allude to the uncertainty that surrounded the 2015 general elections in Nigeria. Figure 2 reveals that Nigeria's GDP surpasses that of Ghana within the period under consideration and in Figure 3, life expectancy at birth for Ghana outweighs what is obtainable in Nigeria despite what was obtained in Figure 2. Literacy rate trends were presented in Figure 4 for both African nations. The behavior of the trends affirms that from 2002 literacy rate in Ghana was improved and rose over that of Nigeria. However, in the pre-2002 era, Nigeria had a literacy rate advantage over Ghana. In Figure 5 , the environmental dimension of sustainable development was captured using $\mathrm{CO}_{2}$ emission as a ratio of GDP. The trends reveal that between 2000 and 2006 the $\mathrm{CO}_{2}$ emission level was higher in Nigeria, but the trends reversed from 2006 till date with Ghana experiencing a higher $\mathrm{CO}_{2}$ emission than Nigeria. Figure 6 presents the proportion of public social expenditure (PSE) to GDP for both countries with Ghana having a more significant proportion than Nigeria except for 2003 when Nigeria marginally allotted more to PSE than Ghana. This is responsible for the better health and education indices for Ghana. Finally, Figure 7 presents the gross fixed capital formation (GFCF) in Nigeria and Ghana with the trends implying that Nigeria led Ghana at all times. In recent times, while GFCF in Nigeria is on the increase, that of Ghana is decreasing.

\section{-Pre-Estimation Analysis}

Table 1 and 2 (see Appendix-II \& III) present the summary statistics for Nigeria and Ghana. The statistical evidence from the table shows that on the average, Nigeria had a better record on gross domestic product, foreign direct investment, capital formation and $\mathrm{CO}_{2}$ emission over Ghana. However, the case is the direct opposite for other variables such as public social expenditure, literacy rate, and life expectancy at birth where Ghana outperformed Nigeria tremendously. This preliminary finding implies that Ghana performs better than Nigeria on social sustainability, which is measured in terms of education and healthcare indicators. However, on environmental and economic sustainability, Nigeria fares better than Ghana. These pre-estimation findings require further empirical inquiry. Thus, the paper proceeds to advanced analysis, such as the unit root test and the estimation of empirical models. 


\section{-Unit Root Test}

Table 3 and 4 contain the group unit root test summary for Nigeria and Ghana, respectively. The probability values of the Levin, Lin and Chu t-test, Im, Pesaran and Shin W-test, the ADF-Fisher ChiSquare test, and the PP-Fisher Chi-Square test which are less than $0.05 \mathrm{imply}$ that the variables are stationary at levels for both countries. Thus, the ordinary least square (OLS) is considered to be a suitable technique for the model parameters estimation.

\begin{tabular}{lcccc}
\hline Method & Statistic & Prob. $^{* *}$ & $\begin{array}{c}\text { Cross- } \\
\text { sections }\end{array}$ & Obs \\
\hline Null: unit root (assumes common unit root process) & & \\
\hline Levin, Lin \& Chu t* & -3.58807 & 0.0002 & 7 & 125 \\
Breitung $t$-stat & -0.99383 & 0.1602 & 7 & 118 \\
& & & & \\
Null: unit root (assumes individual unit root process) & & 125 \\
\hline Im, Pesaran and Shin W-stat & -2.70220 & 0.0034 & 7 & 125 \\
ADF - Fisher Chi-square & 31.6364 & 0.0045 & 7 & 126 \\
PP - Fisher Chi-square & 40.3892 & 0.0002 & 7 & \\
\hline Source: Authors' Computation & & & \\
** Probabilities for Fisher tests are computed using an asymptotic Chi-square distribution. \\
All other tests assume asymptotic normality.
\end{tabular}

Table 3. Group Unit Root Test (Nigeria)

\begin{tabular}{lcccc}
\hline Method & Statistic & Prob. ${ }^{* *}$ & $\begin{array}{c}\text { Cross- } \\
\text { sections }\end{array}$ & Obs. \\
\hline Null: unit root (assumes common unit root process) & & \\
\hline Levin, Lin \& Chu $t^{*}$ & -2.52028 & 0.0059 & 7 & 121 \\
Breitung t-stat & 0.68340 & 0.7528 & 7 & 114 \\
& & & & \\
Null: unit root (assumes specific unit root process) & & 121 \\
\hline Im, Pesaran and Shin W-stat & -2.47730 & 0.0066 & 7 & 121 \\
ADF - Fisher Chi-square & 27.5592 & 0.0163 & 7 & 126 \\
PP - Fisher Chi-square & 22.3653 & 0.0714 & 7 & \\
\hline Source: Authors' Computation & & & \\
** Probabilities for Fisher tests are computed using an asymptotic Chi-square distribution. \\
All other tests assume asymptotic normality.
\end{tabular}

Table 4. Group Unit Root Test (Ghana)

\section{Model Estimation}

\section{Model 1: Economic Dimension of Sustainable Development}

Table 5 presents the empirical result of economic sustainability as affected by FDI for both economies. The result reveals that FDI inflow has a positive impact on economic sustainability in Nigeria and Ghana. Interestingly, the size of the impact is the same. This implies that a percent 


\section{Iheanachor \& Ozegbe}

increase in FDI inflow to these countries enhances economic growth and economic sustainability by 0.30 percent. However, we are quick to that the positive impact is statistically insignificant. The result further shows that gross fixed capital formation has a positive and significant impact on economic sustainability in both economies. Though the size of the effects is different, Nigeria has a pronounced response of 0.58 percent to every 1 percent rise in gross fixed capital formation, while Ghana records 0.47 percent response. This implies that the difference in economic growth and economic sustainability in both countries is not accounted for by FDI both gross fixed capital formation.

\begin{tabular}{lll}
\hline & \multicolumn{2}{c}{ Dependent Variable: $\mathbf{L N G D P}$} \\
\hline & Nigeria & Ghana \\
\hline Explanatory Variables & Parameter $(\boldsymbol{p}$-value) & Parameter $(\boldsymbol{p}$-value $)$ \\
\hline C & $-4.56(0.0090)^{* *}$ & $-3.40(0.0125)^{*}$ \\
LNFDI & $0.03(0.8300)$ & $0.03(0.7384)$ \\
LNGFCF & $0.58(0.0000)^{* *}$ & $0.47(0.0040)^{* *}$ \\
\hline R-Squared & 0.89 & 0.89 \\
$f$-statistic & 65.1881 & 68.9375 \\
Prob- $f$ statistic & $0.0000^{* *}$ & $0.0000^{* *}$ \\
\hline Source: Authors' Computation using Eviews & \\
$* *$ and * imply 1\% and 5\% significance levels & \\
\end{tabular}

Table 5. OLS Result for Economic Sustainability in Nigeria and Ghana

\section{MODEL 2: Social Dimension of Sustainable Development}

Model 2, as presented in Table 6, shows social sustainability and FDI nexus in both countries. The result indicates that FDI has a positive but statistically insignificant impact on social sustainability in Nigeria and Ghana. However, the impact of FDI on social development is higher in the latter than the former. Again, the impact of economic growth on social development shows a conflicting result for both countries. For instance, in Nigeria, rising growth causes falling social development, while in Ghana, it propels social development. The case of Nigeria is so because growth is mostly not inclusive.

\section{MODEL 3: Environmental Dimension of Sustainable Development}

The summary of model 3 is contained in Table 7 on the impact of FDI on environmental sustainability gauged by the level of $\mathrm{CO}_{2}$ emission as a proportion of GDP in both countries. It is evident from the result that $\mathrm{FDI}$ enhances environmental sustainability in both countries through a reduction in $\mathrm{CO}_{2}$ emission. However, its impact is not statistically significant. Furthermore, the impact of growth on environmental sustainability differs on both countries. For Nigeria, higher growth diminishes the level of environmental sustainability through an increase in the $\mathrm{CO}_{2}$ emission. However, Ghana's case is the 
other way round due to better environmental regulatory standards in the former than the latter. Thus, economic sustainability ultimately promotes social sustainability in Nigeria but environmental sustainability in Ghana.

\begin{tabular}{lll}
\hline & Dependent Variable: PSE/GDP \\
\hline & Nigeria & Ghana \\
\cline { 2 - 3 } Explanatory Variables & Parameter (P-Value) & Parameter (P-Value) \\
\hline C & $-9.40(0.6719)$ & $-17.16(0.0831)^{\dagger}$ \\
LNFDI & $2.25(0.2185)$ & $0.9779(0.5313)$ \\
LNGDP & $-1.99(0.1948)$ & $7.59(0.1578)$ \\
\hline R-Squared & 0.11 & 0.60 \\
F-statistic & 1.0300 & 12.2198 \\
Prob-F statistic & 0.3795 & $0.0006^{* *}$ \\
\hline Source: Authors' Computation using Eviews & \\
$* *$ and $\dagger$ imply 1\% and 10\% significance levels &
\end{tabular}

Table 6. OLS Result for Social Sustainability in Nigeria and Ghana

\begin{tabular}{lll}
\hline & \multicolumn{2}{c}{ Dependent Variable: $\boldsymbol{C O}_{2}$} \\
\hline & Nigeria & Ghana \\
\hline Explanatory Variables & Parameter $(\boldsymbol{p}$-value) & Parameter $(\boldsymbol{p}$-value $)$ \\
\hline C & $1.69(0.0000)^{* *}$ & $0.55(0.0000)^{* *}$ \\
LNFDI & $-0.016(0.1076)$ & $-0.004(0.7035)$ \\
LNGDP & $0.168(0.0000)^{* *}$ & $-0.040(0.2844)$ \\
\hline R-Squared & 0.95 & 0.43 \\
$f$-statistic & 176.2360 & 6.0898 \\
Prob- $f$ statistic & $0.0000^{* *}$ & $0.0108^{* *}$ \\
\hline Source: Authors' Computation using Eviews & \\
** imply 1\% significance level &
\end{tabular}

Table 7. OLS Result for Environmental Sustainability in Nigeria and Ghana

\section{DISCUSSION}

The pioneering Harrod-Domar theory $(1939,1946)$ emphasizes the significance of investment as a critical determinant of economic performance. As such, Nigeria and Ghana, like other emerging economies, are open to receiving international flows like FDI in order to ensure economic, social, and environmental sustainability (Hsiao and Shen, 2003). In line with the Harrod-Domar theory (1939, 1946), this particular study has revealed that FDI positively impacts the Nigerian and Ghanaian economies' economic, social, and environmental sustainability. However, it must be noted that the impact is statistically insignificant. In emerging economies like Nigeria and Ghana, lack of capital holds back economic, social, and environmental sustainability. Therefore, boosting FDI inflows could lead to sustainable development in both economies. 


\section{Iheanachor \& Ozegbe}

The study estimated three models based on the three dimensions of sustainable developmenteconomic, social, and environmental. This was done in a bid to evaluate the impact of FDI inflows on the respective dimensions. The empirical finding from the first model of this study reveals that FDI inflow positively impacts economic sustainability in Nigeria and Ghana. Interestingly, the size of the impact is the same. This implies that a percent increase in FDI inflow to these countries enhances economic growth and economic sustainability. This is consistent with Srinivasan et al. (2011), who examined the long-run relationship between FDI and GDP for SAARC economies and found a positive relationship between both variables. In the second model, the result indicates that FDI has a positive but statistically insignificant impact on Nigeria and Ghana's social sustainability. However, the impact of FDI on social development is higher in the latter than in the former. This result is in line with Flora and Agrawal (2017), whose investigation revealed a robust causal linkage running from FDI to enhanced skilled labor wage, advanced technology and social sustainability. It is evident from the third model that FDI enhances environmental sustainability in both countries through a reduction in $\mathrm{CO}_{2}$ emission. This result corroborates Gohou and Soumare (2012), whose study revealed that FDI influences the environmental and economic components of sustainable development in Africa.

\section{CONCLUSION}

The findings of this study revealed that Ghana performs better than Nigeria on social sustainability, which is measured in terms of education and healthcare indicators. However, on environmental and economic sustainability, Nigeria fares better than Ghana. These pre-estimation findings require further empirical inquiry.

This implies that a percent increase in FDI inflow to these countries enhances economic growth and economic sustainability by 0.30 percent. However, we are quick to indicate that the positive impact is statistically insignificant. This reveals that the difference in economic growth and economic sustainability in both countries is not accounted for by FDI and gross fixed capital formation.

However, the impact of FDI on social development is higher in the latter than the former. Again, the impact of economic growth on social development shows a conflicting result for both countries. For instance, in Nigeria, rising growth causes falling social development, while in Ghana, it propels social development. The case of Nigeria is so because growth is mainly not inclusive. The empirical result shows that there is improved environmental sustainability in both countries due to reduction in $\mathrm{CO}_{2}$ emission within the period under review. However, its impact is not statistically significant. Furthermore, the effect of growth on environmental sustainability differs in both countries. For Nigeria, higher growth diminishes the level of environmental sustainability through an increase in the $\mathrm{CO}_{2}$ 
emission. However, Ghana's case is the other way round due to better environmental regulatory standards in the former than the latter.

\section{IMPLICATIONS}

In line with the Harrod- Domar theory $(1939,1946)$, this particular study has revealed that FDI has a positive impact on the Nigerian and Ghanaian economies' economic, social, and environmental sustainability. However, it must be noted that the impact is statistically insignificant. In emerging economies like Nigeria and Ghana, lack of capital holds back economic, social, and environmental sustainability. Therefore, boosting FDI inflows could lead to sustainable development in both economies. The study's result supports the fact that social, environmental, and economic conditions are critical considerations for the inflows of FDI. The study used the ground-breaking Harrod-Domar theory $(1939,1946)$ to empirically ascertain how FDI influences sustainable development through health, education, environment and growth.

On a practical note, the state plays a critical role in these economies' overall operations; as such, the government of both countries should provide adequate infrastructure and policy framework that will be guaranteed a conducive business environment for domestic and foreign investments to thrive.

Therefore, there is a need for the government in both countries to be formulating investment policies that will be favorable to local investors to complement the inflow of investment from abroad. Given the causal link among gross fixed capital formation, foreign direct investment, and sustainable growth and development in both economies, favorable interest rate policies should be formulated and implemented to enhance domestic investment and attract foreign capital inflows.

\section{LIMITATIONS AND FUTURE DIRECTIONS}

This study examined the significance of FDI and its impact on the Nigerian and Ghanaian economies' economic, social, and environmental sustainability. However, the study has some limitations and criticisms that could form the basis of future research endeavors. The findings are based on a twocountry analysis, implying that the result may be difficult to generalize, although it is most likely that the findings apply to many emerging economies apart from the two countries investigated. Future studies can focus on investigating the interactions between FDI, economic, social, and environmental sustainability by conducting cross-country analysis of this relationship to ensure generalization of their findings. Methodologically, future studies can improve on present study by employing more sophisticated analytical techniques such as VAR, ARIMA, ARDL, and Maximum Likelihood (ML).

There is no extant theory in the economic literature that specifically elucidated the relationship 


\section{Iheanachor \& Ozegbe}

between FDI and sustainable development. As such, a scientifically developed theory needs to be formulated in this regard, such that future empirical studies can either confirm or contradict the postulations of such a theory.

\section{REFERENCES}

Acquah, A. M., \& Ibrahim, M. (2020). Foreign direct investment, economic growth and financial sector development in Africa. Journal of Sustainable Finance and Investment, 10(4): 315-334. https://doi.org/10.1080/20430795.2019.1683504

Alfaro, L. (2017). Gains from foreign direct investment: Macro and micro approaches. The World Bank Economic Review, 30(1): 2-15. https://doi.org/10.1093/wber/lhw007

Antwi, S., Mills, E. F. E. A., Mills, G. A., \& Zhao, X. (2013). Impact of foreign direct investment on economic growth: Empirical evidence from Ghana. International Journal of Academic Research in Accounting, Finance and Management Sciences, 3(1): $18-25$.

Agyemang, O., Gbettey, C., Gatsi, J., \& Acquah, I. (2019). Country-level corporate governance and foreign direct investment in Africa. Corporate Governance, 19(5): 1133-1152. https://doi.org/10.1108/CG-07-2018-0259

Akpo, E. S., \& Hassan, S. (2015). Institutional quality matter: an empirical investigation of foreign direct investment in Nigeria. E-Journal of the Social Science Researches, 3(1): 60-73.

Bermejo Carbonell, J., \& Werner, R. A. (2018). Does foreign direct investment generate economic growth? A new empirical approach applied to Spain. Economic Geography, 94(4), 425-456. https://doi.org/10.1080/00130095.2017.1393312

Boianovsky, M. (2017). Optimum saving and growth: Harrod on dynamic welfare economics. Oxford Economic Papers, 69(4): 1120-1137. https://doi.org/10.1093/oep/gpx015

Choi, Y. J., \& Baek, J. (2017). Does FDI really matter to economic growth in India? Economies, 5(2): $20-32$. https://doi.org/10.3390/economies5020020

Coccia, M. (2019). Theories of the evolution of technology based on processes of competitive substitution and multi-mode interaction between technologies. Journal of Economics Bibliography, 6(2): 99-109. https://doi.org/10.1453/jeb.v6i2.1889

Dinh, T. T. H., Vo, D. H., \& Nguyen, T. C. (2019). Foreign direct investment and economic growth in the short run and long run: Empirical evidence from developing countries. Journal of Risk and Financial Management, 12(4): 1-16.

Domar, E. (1957). A Soviet model of growth. Essays in the theory of economic growth. Oxford University Press.

Djokoto, J. G. (2012). Does causal relationships exist between external trade and foreign direct investment flow to agriculture in Ghana? International Journal of Business and Management, 7(2): 179-193. https://doi.org/10.5539/IJBM.V7N2P179

Egbunike, F. C., Emudainohwo, O. B., \& Gunardi, A. (2018). Tax revenue and economic growth: A study of Nigeria and Ghana. Signifikan: Jurnal IImu Ekonomi, 7(2): 213-220. https://doi.org/10.15408/sjie.v7i2.7341

Eltis, D., Emmer, P. C., \& Lewis, F. D. (2016). More than profits? The contribution of the slave trade to the Dutch economy: assessing Fatah-Black and Van Rossum. Slavery \& Abolition, 37(4): 724-735. https://doi.org/10.1080/0144039X.2016.1242905

Evans, O., \& Kelikume, I. (2018). The effects of foreign direct investment, trade, aid, remittances and tourism on welfare under terrorism and militancy. International Journal of Management, Economics and Social Sciences, 7(3): $206-232$. http://dx.doi.org/10.32327/IJMESS.7.3.2018.14

Flora, P., \& Agrawal, G. (2017). FDI and economic growth nexus for the largest FDI recipients in Asian emerging economies: a panel co-integration analysis. International Business Strategy, 1(2): 261-275.

Frimpong, S. K. (2012). Research on relationship between China and Ghana: Trade and foreign direct investment (FDI). Journal of Economics and Sustainable Development, 3(7): 51-61.

Gohou, G., \& Soumaré, I. (2012). Does foreign direct investment reduce poverty in Africa and are there regional differences? World Development, 40(1): 75-95. http://dx.doi.org/10.1016/j.worlddev.2011.05.014

Harrod, R. F. (1948). Towards a Dynamic Economics: Some recent developments of economic theory and their application to policy. London: MacMillan and Company.

Hsiao, C., \& Shen, Y. (2003). Foreign direct investment and economic growth: the importance of institutions and urbanization. Economic Development and Cultural Change, 51(4): 883-896. http://dx.doi.org/10.1086/375711

Insah, B., \& Ofori-Boateng, K. (2012). A model of price determination and fiscal policy in Ghana. International Journal of Development and Sustainability, 1(3): 1-8.

Koojaroenprasit, S. (2012). The impact of foreign direct investment on economic growth: A case study of South Korea. International Journal of Business and Social Science, 3(21): 782-804.

Masipa, T. S. (2018). The relationship between foreign direct investment and economic growth in South Africa: Vector error correction analysis. Acta Commercii, 18(1): 1-8. https://doi.org/10.4102/ac.v18i1.466

Masoud, N. (2014). A contribution to the theory of economic growth: Old and new. Journal of Economics and International Finance, 6(3): 47-61. https://doi.org/10.5897/JEIF2013.0518

Melane-Lavado, A., Álvarez-Herranz, A., \& González-González, I. (2018). Foreign direct investment as a way to guide the innovative process towards sustainability. Journal of Cleaner Production, 172(1): 3578-3590. https://doi.org/10.1016/j.jclepro.2017.03.131 
International Journal of Management, Economics and Social Sciences

Pandya, V., \& Sisombat, S. (2017). Impacts of foreign direct investment on economic growth: empirical evidence from Australian economy. International Journal of Economics and Finance, 9(5): 121-131.

Peprah, P. A., Hongxing, Y., \& Pea-Assounga, J. B. B. (2019). Regional Foreign Direct Investment Potential in Selected African Countries. International Journal of Economics and Finance, 11(10): 66-76. https://doi.org/10.5539/ijef.v11n10p66

Sakyi, D., \& Egyir, J. (2017). Effects of trade and FDI on economic growth in Africa: an empirical investigation. Transnational Corporations Review, 9(2): 66-87. https://doi.org/10.1080/19186444.2017.1326717

Shuaib, I. M., Dania, E. N., Imaogene, I., \& Pogoson, O. O. (2015). The Impact of Foreign Direct Investment (FDI) on the Growth of the Nigerian Economy. International Journal of Research in Business Studies and Management, 11(3): $121-143$.

Siddique, H. M. A., Ansar, R., Naeem, M. M., \& Yaqoob, S. (2017). Impact of FDI on economic growth: Evidence from Pakistan. Bulletin of Business and Economics, 6(3): 111-116.

Srinivasan, P., Kalaivani, M., \& Ibrahim, P. (2011). An empirical investigation of foreign direct investment and economic growth in SAARC nations. Journal of Asia Business Studies. 5(2): 232-248 https://doi.org/10.1108/15587891111152366

Umoh, O. J., Jacob, A. O., \& Chuku, C. A. (2012). Foreign direct investment and economic growth in Nigeria: An analysis of the endogenous effects. Current Research Journal of Economic Theory, 4(3): 53-66.

Voica, M. C., Panait, M., \& Haralambie, G. A. (2015). The Impact of Foreign Direct Investment on Sustainable Development. Petroleum-Gas University of Ploiesti Bulletin, Technical Series, 67(3): 605-613.

Zekarias, S. M. (2016). The impact of foreign direct investment (FDI) on economic growth in Eastern Africa: Evidence from panel data analysis. Applied Economics and Finance, 3(1): 145-160. 


\section{Iheanachor \& Ozegbe}

\section{Appendix-1}

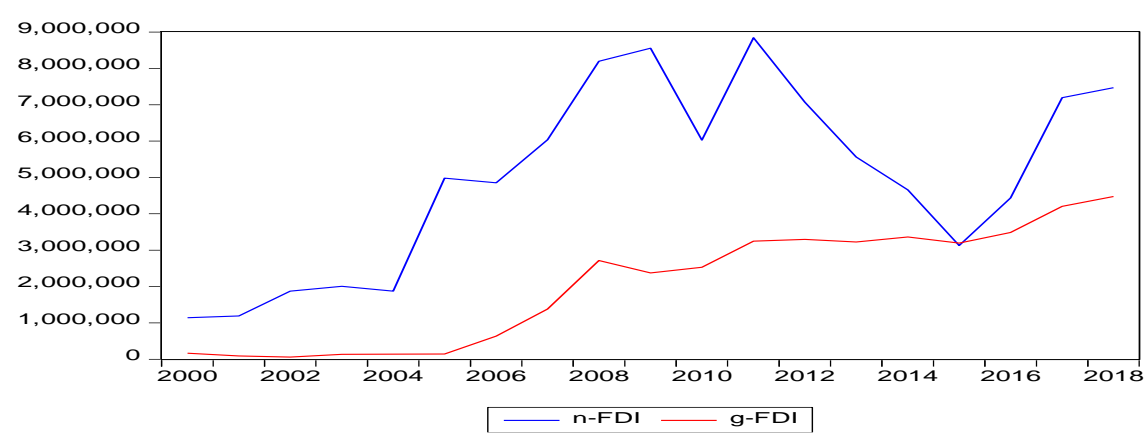

Source: Authors' Computation using World Bank Data (WDI) 2018

Figure 1. Trends in FDI Inflows to Nigeria (n-FDI) and Ghana (g-FDI) in (US\$b)

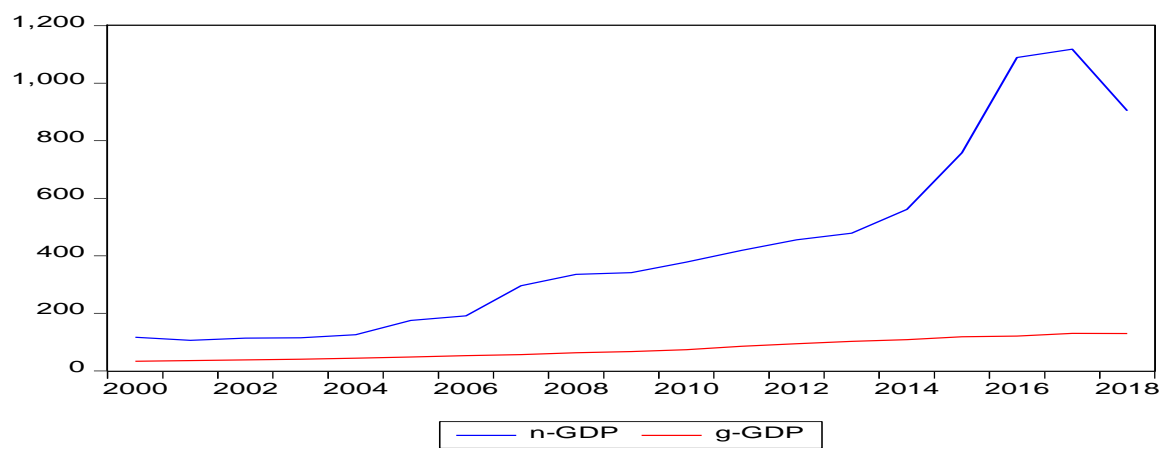

Source: Authors' Computation using World Bank Data (WDI) 2018

Figure 2. Trends in RGDP for Nigeria and Ghana (US\$b)

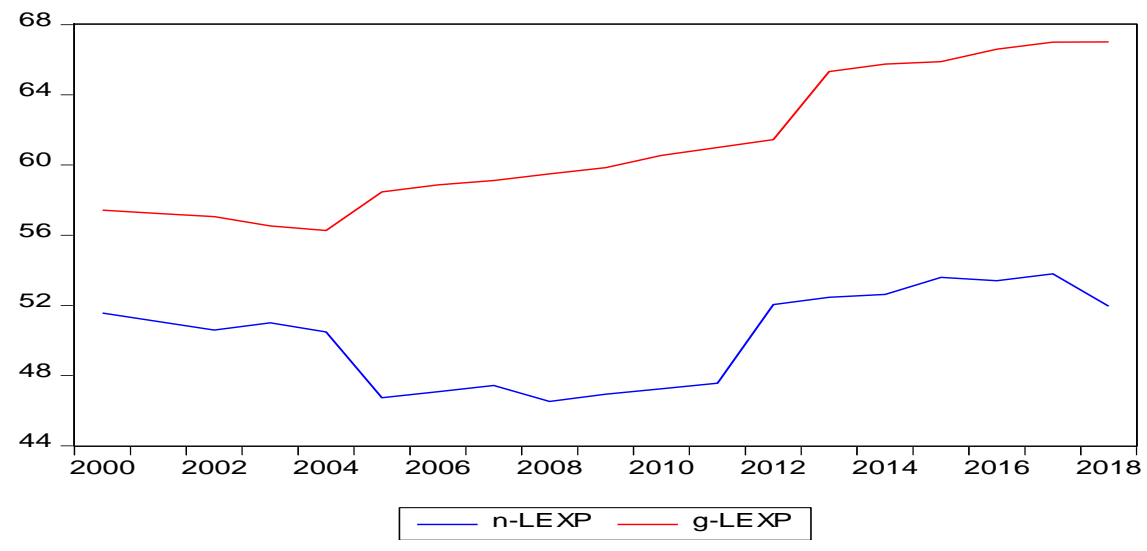

Source: Authors' Computation using World Bank Data (WDI) 2018

Figure 3. Trends in Life Expectancy at Birth in Nigeria and Ghana (2000-2018) 
International Journal of Management, Economics and Social Sciences

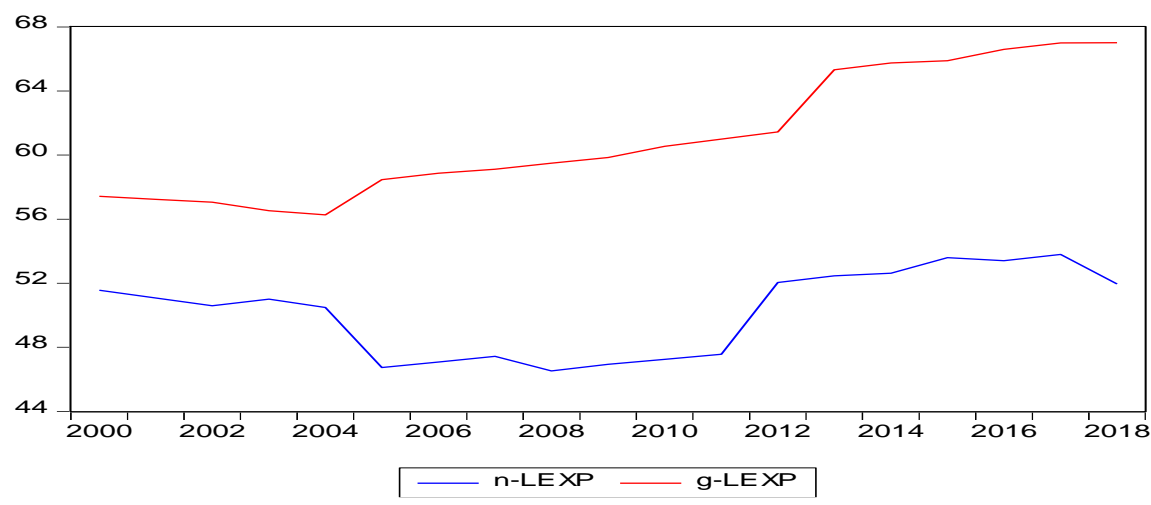

Source: Authors' Computation using World Bank Data (WDI) 2018

Figure 4. Trends in Literacy rate in Nigeria and Ghana (\%)

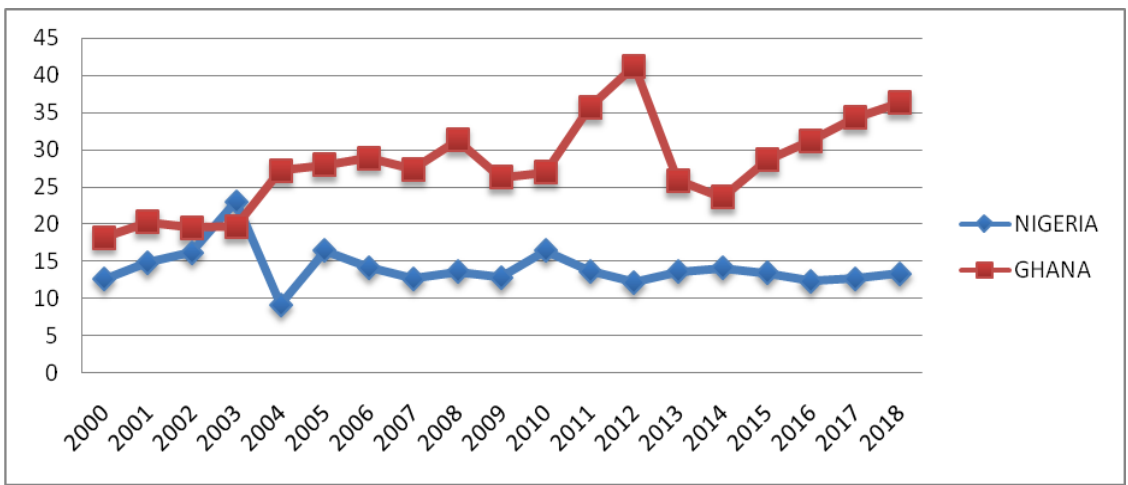

Source: Authors' Computation using World Bank Data (WDI) 2018

Figure 5. Trends in $\mathrm{CO}_{2}$ Emission in Nigeria and Ghana (\% of GDP)

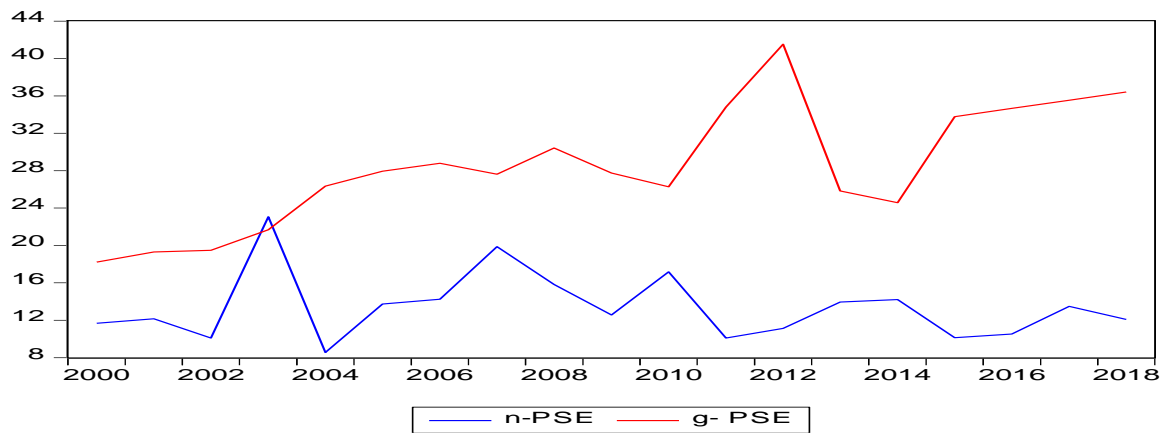

Source: Authors' Computation using World Bank Data (WDI) 2018

Figure 6. Trends in Public Social Expenditure (\% GDP) in Nigeria and Ghana 
Iheanachor \& Ozegbe

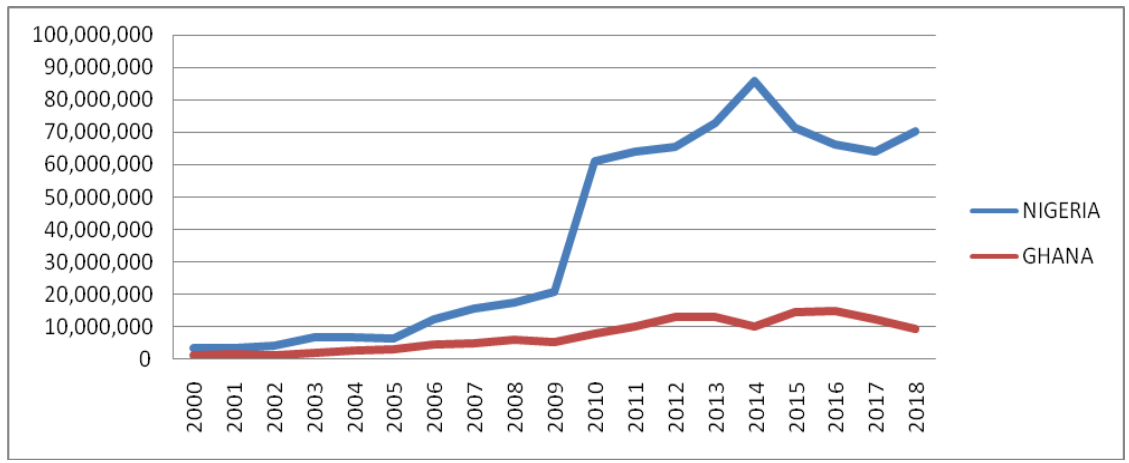

Source: Authors' Computation using World Bank Data (WDI) 2018

Figure 7. Trends in Gross Fixed Capital Formation (US\$b) in Nigeria and Ghana 
Appendix-II

\begin{tabular}{llllllll}
\hline & GDP & FDI & CO2 & GFCF & LEXP & LITR & PSE \\
\hline Mean & 425.1237 & 5004577. & 0.300805 & 41231984 & 50.21759 & 62.30088 & 13.40324 \\
Median & 341.1000 & 4982534. & 0.248000 & 20487180 & 51.01000 & 63.00000 & 12.57173 \\
Maximum & 1118.000 & 8841114. & 0.549000 & 95245835 & 53.80000 & 68.00000 & 23.06111 \\
Minimum & 105.9000 & 1140138. & 0.068026 & 3255315. & 46.53000 & 58.03118 & 8.560376 \\
Std. Dev. & 326.1090 & 2550740. & 0.150663 & 35574148 & 2.633841 & 2.939225 & 3.599823 \\
Skewness & 0.977720 & -0.130902 & 0.256625 & 0.218131 & -0.211976 & 0.225482 & 1.193586 \\
Kurtosis & 2.817625 & 1.772730 & 1.978777 & 1.302596 & 1.477910 & 2.014490 & 4.085783 \\
Jarque-Bera & 3.053461 & 1.246664 & 1.034171 & 2.431606 & 1.976391 & 0.929891 & 5.444697 \\
Probability & 0.217245 & 0.536155 & 0.596256 & 0.296472 & 0.372248 & 0.628169 & 0.065720 \\
Sum & 8077.350 & 95086955 & 5.715290 & $7.83 \mathrm{E}+08$ & 954.1342 & 1183.717 & 254.6615 \\
\hline Sum Sq. Dev. & 1914247. & $1.17 \mathrm{E}+14$ & 0.408591 & $2.28 \mathrm{E}+16$ & 124.8681 & 155.5028 & 233.2571 \\
\hline Source:Aus & & & & & & & \\
\hline
\end{tabular}

Source: Authors' Computation using Eviews

Table 1. Summary Statistics for Nigeria 


\begin{tabular}{llllllll}
\hline & GDP & FDI & GFCF & LEXP & LITR & CO2 & PSE \\
\hline Mean & 75.97191 & 2045486. & 6861529. & 61.09984 & 72.32412 & 0.320350 & 28.47233 \\
Median & 67.28900 & 2527350. & 6119681. & 59.85000 & 73.20000 & 0.321000 & 27.74000 \\
Maximum & 130.2210 & 4477590. & 13441025 & 67.01699 & 78.84382 & 0.377000 & 41.53000 \\
Minimum & 33.47600 & 58930.00 & 1150985. & 56.27000 & 57.90000 & 0.258000 & 18.23000 \\
Std. Dev. & 34.04930 & 1590291. & 4420944. & 3.886036 & 5.367263 & 0.037932 & 6.424139 \\
Skewness & 0.326231 & -0.124133 & 0.138167 & 0.427894 & -1.524071 & 0.094289 & 0.160497 \\
Kurtosis & 1.640747 & 1.457562 & 1.593586 & 1.649173 & 4.933670 & 1.760510 & 2.288919 \\
Jarque-Bera & 1.799676 & 1.932262 & 1.626369 & 2.024376 & 10.31561 & 1.244419 & 0.481867 \\
Probability & 0.406635 & 0.380553 & 0.443444 & 0.363423 & 0.005754 & 0.536757 & 0.785894 \\
Sum & 1443.466 & 38864231 & $1.30 \mathrm{E}+08$ & 1160.897 & 1374.158 & 6.086650 & 540.9743 \\
Sum Sq. Dev. 20868.38 & $4.55 \mathrm{E}+13$ & $3.52 \mathrm{E}+14$ & 271.8230 & 518.5352 & 0.025899 & 742.8521 \\
\hline
\end{tabular}

Table 2. Summary Statistics for Ghana 